\title{
Imagining Alternative and Better Worlds: Isabel Fletcher Talks with Adele E. Clarke'
}

\author{
ISABEL FLETCHER \\ UNIVERSITY OF EDINBURGH \\ ADELE E. ClARKE \\ UNIVERSITY OF CALIFORNIA SAN FRANCISCO
}

\begin{abstract}
In this interview, Adele Clarke and Isabel Fletcher discuss the different routes that led Clarke to science and technology studies (STS), the field's increasing engagement with biomedical topics, and her perspectives on its character today. Clarke describes how women's health activism and teaching feminist critiques of bioscience/biomedicine led her to participate in academic networks now known as feminist STS and trans-national reproduction studies. She reflects on the importance of inter-/trans-disciplinary collaboration in her work, but also raises concerns that the rapid expansion of the field has resulted in inadequate training for newcomers in the "theorymethod packages" of STS, and hence poor quality scholarship. For her, the future of STS lies in approaches analyzing the complex intersections between technoscience, gender, race, (post)coloniality, and indigenous knowledges, and in its expansion beyond Europe and North America, to Asia, Central and South America, and Africa. In her following reflection, Isabel Fletcher considers the importance of inter/trans-disciplinarity for STS and highlights the role a politically engaged STS can play in imagining alternative and better worlds.
\end{abstract}

\section{Keywords}

Interview; Adele Clarke; feminist STS; post-coloniality; trans-/inter-disciplinarity; methods

\footnotetext{
${ }^{1}$ I am honored to join in reflecting on the past, present and future of STS, by which I mean both feminist and non-feminist science, technology, and medicine studies. With sadness, I dedicate this interview to the memory of Leigh Star, my earliest mentor into STS (Bowker et al., 2015). Some of the ideas here appeared in Clarke (2016). I thank the Edinburgh team, especially Isabel Fletcher, and my colleagues Warwick Anderson, Geof Bowker, Monica Casper, Jia-shin Chen, Mike Levesque, Sara Shostak, and Rachel Washburn for valuable comments and assistance, and Monica for an especially close read on short notice.

2 Isabel Fletcher, Email: I.Fletcher@ed.ac.uk

3 Adele E. Clarke, Email: adele.clarke@ucsf.edu

Copyright ( 2018 (Isabel Fletcher, Adele R. Clarke. Licensed under the Creative Commons Attribution Non-commercial No Derivatives (by-nc-nd). Available at estsjournal.org.
} 


\section{STS Origin Stories and Political Engagements}

IF How did you become involved in STS?

AC I came to STS through several routes. First, I began teaching women's studies and women's health (including history courses) in 1973, which drew me into critiques of medicalization and bioscience/biomedicine. Second was the West Coast Socialist Feminist Study Group where, in the late 1970s, I met Donna Haraway, Judy Stacey, Gayle Rubin and others. Third, my women's health activism shaped my early feminist STS vision and scholarship. I worked with the Committee to Defend Reproductive Rights on sterilization abuse, a vicious form of medical racism, often (but not always) with eugenic roots (Clarke 1983). We published on such topics in The Socialist Review produced by San Francisco Bay Area scholars, grad students, and community activists. Donna Haraway's (1985) "cyborg manifesto" first appeared there, as did my work on anti-racist organizing for sterilization regulations (Clarke and Wolfson 1984). This work was part of broader initiatives in both feminist STS, and what became trans-disciplinary and transnational reproduction studies. Last, when I returned to grad school in 1980 for my PhD at UCSF, I met Leigh Star, also a long time feminist who had participated in the Genes and Gender projects at Radcliffe (Star 1979). Soon, Joan Fujimura from Berkeley joined our STS study group. We were medical sociologists by specialty and our advisor, interactionist Anselm Strauss, was deeply interested in the intersections among sciences, technologies and medicine throughout his career. Together, we attended our first 4S (Society for Social Studies of Science, f. 1975) meetings in Philadelphia in 1982 and I was immediately hooked. I was not a lapsed scientist, nor did I have a background in science or STS. But these were among the smartest scholars I had ever met, and the meetings were intellectually thrilling--which I assuredly had not experienced at American Sociological Association conferences. I quickly changed my dissertation topic. Our group taught ourselves STS as there was no coursework, although Berkeley sociologist Troy Duster (Joan's advisor) was working on race and heredity/genetics. He graciously hosted a supportive and provocative working group. The decision I made to specialize in STS as well as medical sociology was the most important in my career.

IF How do you understand the origins of the field of Science and Technology Studies (STS)?

AC The origins stories I tend to tell center around groups of scholars who eventually came together to form EASSTS (the European Association for the Study of Science and Technology), 4S and other professional organizations and to found journals such as Social Studies of Science and Science, Technology and Human Values, among others. One "core set" (Collins 1983) was composed of the various STS and science, computing and society organizations in Scandinavia where social scientists were asking STS kinds of questions especially vis-a-vis technology and labor force policy issues, in units often linked to governments. Another quite different core set included the burgeoning STS units at Edinburgh, Bath, the Center for the Study of Innovation at the École des Mines in Paris, and a group at Bielefeld that included Karen Knorr Cetina, also at Berkeley at the time. Latour and Woolgar's Laboratory Life (1979) and Knorr-Cetina and Mulkay's Science 
Observed (1983) were my magical entrée readings. Yet another strand of early STS was US-based, including some scholars trained in Mertonian sociology of science at Columbia (e.g., Zuckerman 1989). There were also core sets of STS/science policy scholars at Rensselaer Polytechnic Institute (RPI), Virginia Tech, Georgia Tech and elsewhere, and an array of STS-ish policy groups around Washington (some in government and others in NGOS). Progressive social action organizations raising ST\&MS issues included Science for the People (Greeley and Tafler 1980) and Health-Pac (Ehrenreich and Ehrenreich 1970). In North American academia, the History of Science Society (HSS), the Philosophy of Science Society (PSA), and the American Association for the History of Medicine (AAHM) were all established post-WWI, and the Society for the History of Technology (SHOT) post-WWII. However, such disciplinary traditions tended to narrow acceptance of often trans-disciplinary STS work. Significant here, in sociology at that time, we were all identified by theoretical tradition. The concept of paradigm (Kuhn [1962] 1996) had taken deep hold. While the concept did valuable clarification work, the accompanying disciple-like loyalties and competition were far less helpful. I have grown increasingly appreciative of dwelling in a department where trans-disciplinarity is deeply valued (e.g., Casper 2016). Early in the trajectory of STS, Leigh Star was invited to edit a special issue of the journal Social Problems (35:1988) to introduce STS to (especially American) sociology. This became the core of her edited book Ecologies of Knowledge. A paragraph from her introduction captures the spirit of our shared approach in that era:

Our key questions here are those of general political theory and of feminist and third world liberation movements: Cui bono? Who is doing the dishes? Where is the garbage going? What is the material basis for practice? Who owns the means of knowledge production? The approach begins in a very plain way with respect to science and technology by first taking it "off the pedestal" (Chubin and Chu 1989) --by treating science as just something that people do together. Some of this means looking at science and technology as the occasion for people to do political work--not necessarily by other means, but fairly directly. Science as a job, science as practice, technology as the means for social movements and political stances, and science itself as a social problem-collectively, these articles take science/technology as the occasion for understanding the political and relational aspects of what we call knowledge (Star [1995:3] 2015:15).

All these issues continue to be pertinent. In 1986, I was invited by several other sociologists to help form a section of the American Sociological Association focused on STS-Tom Gieryn, Sue Cozzens, Sal Restivo, Daryl Chubin, Henry Etzkowitz and others. We succeeded and, after much debate, it was named the Science, Knowledge and Technology (SKAT) Section (Sweeney 2015). For me, the sociology of knowledge was and remains intellectually central since reading Berger and Luckman (1966) when it appeared. Thus I appreciated the inclusive breadth of the section's name. It has become 
even more apt as topics such as finance and the social sciences have become objects of study. Led by Steven Epstein (2016), the section had a major 25 anniversary event in August, 2015. I have long wondered why an ASA section on the sociology of science had not been established earlier.

IF Can you reflect on the role of the University of Edinburgh's Science Studies Unit in the development of STS as a field?

AC While I never had the opportunity to visit the Edinburgh STS Unit, it has always held a special place for me largely but not only because of David Edge's wondrously avuncular and productively provocative presence in an array of STS venues. His editorship established Social Studies of Science (3S) as "the Mercedes Benz of STS journals," and he maintained it in that enviable position for decades. I still celebrate specially when a former student has a first publication in SSS as this marks one's career with a signal imprimatur! I was also very close to Merriley Borell (now deceased), a Welcome History of Medicine Fellow at Edinburgh and a superb historian of the reproductive sciences, especially British endocrinology. The University of Edinburgh was one of three major British centers of reproductive science. F.H.A. Marshall, author of what I called "the Bible of the reproductive sciences" (Clarke 1998) completed his PhD there. For many in British reproductive sciences, the relations of that science to social issues were both transparent and to be actively engaged in ways that I knew from my research was rarely the case in the US. But David Edge was far from alone at Edinburgh in pioneering STS. Many of the founding STS scholars were there when they made key contributions including Steve Shapin and Simon Schaffer's Leviathan and the Air Pump: (1985) and David Bloor's Knowledge and Social Imagery (1976). Barry Barnes (e.g., 1977) and Donald MacKenzie (e.g., 1978) led the "Edinburgh Interests School," one of the founding traditions. Shapin's (1995) sophisticated review of the field to that date remains invaluable for teaching. Thus it does not surprise me that a robust and vibrant STS unit has endured at Edinburgh for half a century. David Edge embodied its lively perspective on the responsibility of science and scientists, and brought it into STS transnationally through 4S, 3S and EASST (the European Association for the Study of Science and Technology) in important ways that shaped the field.

IF Like all academic disciplines, STS has been shaped by underlying political commitments and concerns. What do you think have been the most significant for the field?

AC The political roots and commitments of STS scholars and projects are fundamental aspects of its being founded as STS and of its development. STS was one among an array of more or less politically-inspired trans-disciplinary fields with roots in what are now called 1960s politics, with earlier progressive roots. That is, if there was a "long civil rights movement" as Alondra Nelson (2013) has recently demonstrated, there was also a "long STS movement." The heritage of engagement of the Edinburgh STS Unit is one

- See http://skat25.com/. Many of the presentations, including my own, were subsequently published in ESTS Vol. 2 (2016). See Thematic Collections: Positioning the Field, http:/ / estsjournal.org/issue/view/8 . 
indicator, but it pertains much more broadly and transnationally (see also Clarke 2016). In the post WWII political history of incipient STS, there were many contributory books (trade and academic), social movements and incipient efforts. These ranged from antinuke and anti-war activism to "Science for the People" as both long-standing inspiration and formal organization (e.g., Greeley and Tafler 1980), to civil rights and feminist, LGBT and disability rights activism, to environmentalism, early animal rights, and so on. Many scientists became involved in various progressive organizations such as " $X$ Scientists for Y." Some were transnational, such as Computer Professionals for Social Responsibility (CPSR), which, from 1983 to 2013, sought to provide input on policy and public debate. Others less formally took on sexism and racism in academic science: R.C. Lewontin, Stephen Jay Gould and Ruth Hubbard of Harvard especially vis-a-vis genetics and evolutionary theory; Ruth Bleier from the Women's Medical College of Pennsylvania visa-vis neurophysiology; and Evelyn Fox Keller from MIT vis-a-vis physics, genetics and molecular biology. The spirit of the day linked Science and Liberation (Arditti, Brennan and Cavrak 1980). Vis-à-vis technology, science studies units of government throughout Scandinavia were often deeply linked to workers unions and occupational health and safety issues regarding the conditions of work-quite lively as computer and information technologies were initially introduced into workplaces. An Office of Technology Assessment was part of the US Congress from 1972-1995, terminated under the neoconservative Reagan presidential administration. It employed sociologists of science (including Daryl Chubin) among others and produced reports on topics including acid rain, health care, global climate change, and polygraphs. In today's political deadlock and profoundly anti-scientific and anti-intellectual zeitgeist in the US, the closure of the OTA is not at all surprising. But in retrospect, it seems to have marked a moment of profound change in how government policies regarding sciences, technologies, medicines and pharmaceuticals were to be formulated. Government sought and sponsored research would no longer inform such policies. Politicians would decide. Within both STS and feminist worlds in the 1970s and after, there were left liberal as well as socialist and (neo)Marxist traditions. Edinburgh interests theorizing (e.g., Barnes 1977; and MacKenzie 1978), especially Donald MacKenzie's (1982) article on "Technology as Capitalist Restructuring" opened my eyes to them. I then happily taught Zilsel ([1942] 2000) on "The Sociological Roots of Science," and Ravetz's (1971) Scientific Knowledge and its Social Problems for decades. I fear awareness of these works has dimmed with the transnational rise of neoliberalism. One could also distinguish segments in STS history that were identity-marker inspired (e.g., ecofeminist, anti-racist, LGB [and later T]). Some sought separate spaces and venues, others attempted integration, and a few sought both. Regardless, all the politics were explicitly marked and discussed in often quite lively and invigorating exchanges both inside and outside academia that I miss! And there were shared concerns among those of us in grad school from the 1960s onwards, that our educations and future scholarship should engage such commitments more explicitly. Not surprisingly, such politics were also lively in the shift from sociology of science to STS 
and SKAT along with various forms of constructionisms and poststructuralisms. This transition from sociology of science had largely occurred by the time I entered STS around 1982.

\section{A Growing Engagement with the Biomedical and the Environmental}

IF Can you reflect on the "trajectory" that STS has taken?

AC Foremost, the growth of STS in terms of both size and scope over the past forty years or so has far surpassed my wildest expectations. It was a small and relatively insular world in certain respects when I entered in 1982, and its dramatic growth since then serves as the backdrop to my remaining remarks. Here I take up two topics I find most significant: the expansion of STS to include a deep focus on things (bio)medical and pharmaceutical (becoming ST\&MS) and the growth of concern and research on environmental and ecological issues, including feminist STS projects. Deeply important to me---and to students I trained in STS---has been the tremendous growth and acceptance of engaging "things (bio)medical." As Amsterdamska and Hiddinga (2004:239,260) noted, 4S presentations on medical topics increased from $11 \%$ in 1988 to $29 \%$ in 2001, and proportions of 35 journal articles shifted similarly. Given developments in the life sciences generally, this proportion has likely expanded. This is significant for several reasons. Foremost, "things (bio)medical" are among the primary sites of intersection of technoscience and people's lives. Hence they offer extremely important analytic sites for STS research and intervention (e.g., Casper and Berg 1995). 4S and SKAT openness to "things (bio)medical" also matter as, despite many valiant efforts on my and others' parts, medical sociology/the sociology health and illness in the US by and large remains unimpressed by the growing salience of technoscience in biomedicine (e.g., Clarke et al. 2010). Second, the growth of environmental/ecological concerns in relation to STS has also been dramatic, manifest across diverse arenas. As Charis Thompson (2005:31) noted, "The single thing that most unites those within the field of STS is an interest in the deep interdependence of nature and society." They are nonfungible. Sophisticated scholars increasingly grasp that sciences--including social sciences-must at heart become posthumanist projects. Thus today in STS, scholars explore what it means that, in Latour's words, "what was until now a mere décor for human history is becoming the principal actor," ${ }_{5}$ and how Staying with the Trouble (Haraway 2016) is requisite for our having livable multispecies futures. In such works we see core issues of early STS finding fertile new grounds. For example, the human- and culture-centeredness of anthropologists is turned upside down by Kohn's (2013) How Forests Think: Toward an Anthropology Beyond the Human. The "animal turn," pioneered by Donna Haraway in her masterwork Primate Visions (1989), has become a lively STS sector, recognized by Hugh

${ }^{s}$ see http:/ / www.bruno-latour.fr/node/ 487 
Raffles' (2011) Insectopedia winning the Fleck Prize. Combining multispecies environmental and population/demographic concerns with reproductive and other feminist issues, Donna Haraway and I organized a session for the 2015 meetings of $4 \mathrm{~S}$ in Denver titled "Make Kin Not Babies: Toward Feminist STS Pro-Kin and Non-Natalist Politics of Population and Environment." While feminist STS scholarship richly addresses reproduction, it has largely been silent about reducing human burdens on planet earth. Quoting from our proposal: "Can we develop anti-colonial, anti-imperialist, anti-racist, STS-informed feminist politics of peopling the earth in current times, when babies should be rare yet precious and real pro-family and community politics for young and old remain rare yet urgently needed? ... Why hasn't feminist STS taken the lead in such fundamental endeavors?" Others attempting to answer this question with us include Michelle Murphy, Kim TallBear, Chia-ling Wu, Yu-ling Huang, and Ruha Benjamin (Clarke and Haraway 2018). The fraught question of "where are the feminist visions?" can be partially addressed by reflecting on the history of STS, especially the "science wars" of the 1990s and the "culture wars" waged ever since, harbingers of the rise of neoliberalism. These wars set STS back in serious ways politically, repressing our progressive roots and critical edges (e.g., Hilgartner 1997; Hess 2009). Yet today they can seem like bad rainstorms compared to the megaforces of anti-climate science discourses and anti-intellectual neoliberal attacks on higher education swirling about (discussed below). The fact that "science is politics pursued by other means" (Latour 1983:167-8) is now hypervisible. Happily, we are also seeing a renaissance of the critical edges of STS and other areas that will only gain in momentum over coming decades. Yet we also live with the nagging fear that we are fiddling while the environment is degraded and the planet denuded and polluted.

IF What aspects of this have been particularly meaningful, compelling, useful or frustrating to you?

AC I have already addressed the compelling issues for me, so here I will attend to a frustration and recommendations to address it. Thanks to STS's tremendous growth and popularity, our specialty now draws many people to present at conferences and submit to journals who are un- or very inadequately trained in the field. Their breath-taking naiveté is painfully obvious to those who know the classic literatures, as core STS issues cut across substantive domains. This makes it all too easy to put one's scholarly foot in one's mouth. Therefore I am using this interview as a platform to call for better training of doctoral students and other newcomers in STS-and what is now the history of STS. Perhaps it is time for on-line STS seminars as well as syllabi collections, etc. Some people find themselves in STS unexpectedly and dwell in institutions lacking any related educational opportunities. STS conferences might offer a session each year of "STS 101: Focus on X" with short syllabi available in advance. These would function as STS orientations-and mixers. In short, if we want the quality of STS scholarship to improve, we need to enhance people's opportunities to learn STS, and to do so in transnational STS venues. 


\section{"I Have Grown Increasingly Appreciative of Dwelling in a Department Where Trans- disciplinarity is Valued"}

IF Can you reflect on the position of STS in relation to other core groups concerned with science and technology (e.g., other academic fields, publics, institutions, policy-makers)? How have those engagements shaped the field?

AC STS entered academia on the tail end of the emergence of an array of new inter- and trans-disciplinary entities that are more or less identity-based (e.g., women's studies, race/ethnicity studies). As in such identity-based areas, there has been struggle and strife both within and among disciplines and specialties that have taken science, technology and medicine studies seriously. This is most especially the case vis-a-vis history, philosophy (including bioethics), and history of medicine or health sciences, but also in sociology (e.g., Casper 2016). Moreover, within the sciences, engineering, and biomedicine, social dimensions of their production and application of knowledge have become of increasing concern. Some curricular facets are "self-serving"---to enhance capacities and STS "consumer" acceptance---but not all. Thus today one finds lone (and often lonely) STS scholars tucked into many odd corners of the academy including medical and engineering education and beyond. Various policy worlds too have become increasingly concerned with the kinds of issues engaged by STS. However, two related trends have had particularly negative effects on the autonomous development of STS. In the US and elsewhere, neoconservative-led "culture wars" were very much directed at STS, among other and sometimes related targets, including as anti-racism, feminism and poststructuralism. Second, neoliberal governance is devastating academia transnationally, most especially but not only in the US and UK. In short, STS emerged as academia contracted.

IF Which groups have been most important for your work?

AC Much of my work has been historical sociology, including history of biology, medicine and agriculture, and I have happily worked with historians in all of those areas. In the 1990s, a group of us had an exciting collaboration that produced both The Expansion of American Biology (Benson, Maienschein and Rainger 1991) and a Special Issue on "Crossing the Borderlands: Biology at Chicago" of Perspectives on Science: Historical, Philosophical, Social in 1993 (v. 1, n. 3). In another thread of my work, since the 1970s, in feminist STS and across the social sciences, reproduction was "dragged to the center of social theory" (Rapp 2001:466). STS-inspired reproduction studies have long been at the heart of my research (e.g., Clarke 1983, 1998), and I participate in the increasingly transnational and transdisciplinary community of scholars that created and sustains this domain. $4 \mathrm{~S}$ has been a comfortable transnational forum for many sessions leading to 
books in this specialty area. ${ }^{\circ}$ Contributing to edited volumes and special issues can be undervalued in some academic venues, but when based on strong collaborations, the breadth of learning and cross-fertilization can be immensely valuable to both contributors and to the broader field. As a junior scholar I was encouraged to engage in such transdisciplinary projects and am very glad I followed that radical advice---from historians no less---which much improved my scholarly life.

\section{"Theory-methods Packages" and Studying the "Postcolonial"}

IF Where do you see STS going today? Related, what do you feel is missing from STS, hasn't been done yet or needs to be explored?

AC I have pulled these two interview questions together because aspects of where I see STS going-what's new? —are actually dimensions of early STS work now being refreshingly revisited (refreshing at least when the early work is grasped, acknowledged and extended). Thus my focus here is less on new topics and more on how to approach topics usefully and innovatively in these times. There has been increasing--and sorely needed-attention to both methods and theorizing in contemporary STS marking, I believe, a deeper consolidation of our endeavor. These are, of course, nonfungible in practice-what Leigh Star (1989a) called "theory-methods packages," now a common core assumption of STS (e.g., Jensen 2014). Early STS projects routinely elucidated methods issues such as the theory-dependence of what counts as data, boundary construction as part of the creation and maintenance of science, the nature of paradigm shifts (going beyond Kuhn) as ongoing displacements of "old truths" (with a small " $\mathrm{t}$ "), and the nature and contingency of objectivities. Contemporary projects are revisiting questions regarding sites of new knowledge production and their practices, and enduringly gnarly problems of how sciences, knowledges and technologies travel. Enter theory. Elsewhere (in my work on methods), I have argued that there has been "a (re)turn toward or reconfiguration of the social" in social theory since c1970 that by and large takes aspects of poststructuralism into account (Clarke, Friese and Washburn 2015:43-47; 2018:62-63). This "turn" has coalesced around several often overlapping or hybrid approaches including (roughly in order of emergence): Bourdieusian and other practice and field theories; interactionist social worlds/arenas theory; Foucauldian theories of discourse and the dispositif; actor-network theory (ANT); and Deleuze and Guattari's assemblage and rhizome theories. These are all relational/ecological approaches, and I would argue, are the major "theory-methods packages" taken up in STS today. Precisely because the

- For example, Anne Saetnan, Nelly Oudshoorn and Marta Kirejczyk (2000) co-edited Bodies of Technology based on such sessions. Similarly, Chia-Ling Wu, Azumi Tsuge and I co-edited a Special Issue on Reproductive Technologies and Gender in East Asia for East Asian Science, Technology and Society (Clarke 2008; Wu et al. 2008). I also had the privilege of participating in the exciting and innovative transdisciplinary "From Generation to Reproduction Project" at Cambridge (Clarke 2007; see http: / / www.reproduction.group.cam.ac.uk/). 
object of study in STS is, broadly speaking, the production of knowledge, the methods of STS practitioners have always already been under scrutiny---if not by authors, then by others. Thus concerns with reflexivity and triangulation of data are "built in" rather than "added on" to the STS methodological tool box, and continue to engage us (e.g., Gad and Ribes 2014; Woolgar and Lezaun 2013). But vis-a-vis method as elsewhere, STS suffers from its own successes. For example, Mike Lynch (2012:452), former editor of Social Studies of Science, recently commented, "[O]ver the past decade, I have been led to the sad conclusion that the volume of BADANT (Banal and Derivative Actor Network Theory) greatly exceeds the well-researched and broadly informative written work that rides under the ANT banner." I can further attest that the same is true for both grounded theory and situational analysis (the extension of grounded theory I developed), having reviewed hundreds of papers for co-edited volumes on these interpretive approaches (Clarke and Charmaz 2014; Clarke, Friese and Washburn 2015). Therefore, I would assert that the future of STS should include greater attention to "theory-methods packages" in STS training. Moreover, there is tremendous need for more explicit critique of these issues in reviewing STS papers and books, a point underscored by my former students' shock at the quality of what they are asked to review. Worse, I have lately read far too many books published by university presses that obviously never went out to appropriate reviewers. Yes, books are needed quickly for tenure, but long-term reputations matter-of scholars, fields and presses. In terms of future directions, I am particularly excited about a set of intersections, relatively invisible in early STS, among technoscience, gender, race, (post)coloniality, and indigeneity (e.g., Benjamin 2016; Prasad 2016; Rodriguez-Muniz 2016). All were clearly and vividly implicated in my initial work on the history of the reproductive sciences, and have been quite lively for me as a scholar. And superb research has been done in these areas over the years, sufficient that I began teaching a course awkwardly titled "Gender, Race and (Post)Coloniality in/and Sciences, Medicines and Technologies" during the 1990s. Even then, one course could barely skim the surface in terms of gender and race vis-a-vis both how each of these categories has been constructed by various sciences and technologies and how the gender(s) and race(s) of the producers of scientific knowledge and various technologies helped shape knowledge and technologies. For feminist and anti-racist scholars, this initial work centered on "low hanging fruit"--very visible and analyzable issues of crucial and broad import. Today, given the plethora of "turns," the challenges in these domains are expanding dramatically and are even more interesting (e.g., Bailey and Peoples 2017). Through close colleagues at UCSF and Berkeley, and through East Asian Science, Technology and Society: An International Journal (EASTS), I became entranced with postcolonial STS as one key to STS future imaginaries. In Warwick Anderson's (2015:652,

- My appreciation here to Warwick Anderson, Vincanne Adams (e.g., Anderson and Adams 2007), Philippe Bourgois, Barbara Koenig, Janet Shim, Howard Pinderhughes, Sharon Kaufman, Deborah Gordon, Ian Whitmarsh, Judith Justice, Paul Rabinow, Lawrence Cohen, Cori Hayden, Charis Thompson and Aihwa Ong. 
emphasis added) recent grapple to define it, he argues: A postcolonial orientation directs attention to the complexities of relations in any contact zone. It re-examines the terrain that empire has tilled across the world, showing that dominance is never absolute-that imperial or authoritative knowledge, despite colonial fantasy and amour propre, must always adapt to local conditions, mix with other traditions, and incorporate difference... Thus an analysis that deconstructs imperial binaries such as nature-culture, moderntraditional, global-local builds on a postcolonial, or decolonizing, platform. Even if explicit recourse to postcolonial theory remains rare in science and technology studies, $a$ postcolonial sensibility has infiltrated its critical scholarship. One key future direction for postcolonial STS is, then, analyzing the "messy, uneven politics and diverse, contending agents amid the historical debris." And such projects can be done vis-à-vis all kinds of sciences, technologies and (bio)medicines all over the planet. Enter "theory-methods packages" for analyzing messy things in complex historical situations far too simply labeled "postcolonial." Here we revisit the significant debate between the early STS concepts of "immutable mobiles" (e.g., Latour 1986; Law and Singleton 2005) and "boundary objects" (e.g., Star [1988] 1989b, 1991, 1995b, 2010; Star and Griesemer 1989). Latour essentially argued that sciences and technologies travel intact through stabilization of their actor-networks. Star countered by asserting that sciences, technologies and "things biomedical" are always and relentlessly (re)interpreted and adapted by those who use them for their own purposes--shaped by wherever they may be. Both travelling and relocating can be sticky and messy. Vis-a-vis postcolonial STS, following Star, nothing travels without being "resituated" according to "local" conditions, needs and requirements of many kinds-including (translated) both expansions of and deletions from networks which must be flexible in order to travel (e.g., Prasad 2016). Thus postcolonial STS provokes broad questions regarding one's "theorymethods package" approach. In her introduction to Ecologies of Knowledge, Star asserted that the key analytic difference was between ecological and reductionist approaches. "In furthering the cause of an ecologically responsible, socially and philosophically sophisticated analysis of science and technology, we need to confront head-on questions of scale, of boundary drawing, ...as well as questions of race, sex, and class. To do that, recursively and reflexively, we need an ecological approach...." (Star 1995:14; 2015:2324). An array of more or less ecological approaches is available today-noted above as part of "the (re)turn to the social" (see also Lury and Wakeford 2012). Also important in one's choice of theory-methods package for pursuing postcolonial STS is the capacity to handle mess. Postcolonial STS projects are inherently multi-cultural, multi-historical, multi-spatial, multiply inflected-in short, multi-most everything-very messy and complex. In both After Method: Mess in Social Science Research and elsewhere, John Law $(2004,2007)$ asserts that simplicity and cleanliness in research are not only over-rated but often useless. "I argue that (social) science should also be trying to make and know realities that are vague and indefinite because much of the world is enacted in that way" (Law 2004:14, emphasis in original). Our project is to observe and analyze in situ. And to do so, 
"We need to understand that our methods are always more or less unruly assemblages" (Law 2007:605). Law (2007:595) brilliantly calls methods that simplify and tidy up life "forms of hygiene." Such methods manage the uncertainties of complexity by building "great walls" to exclude them and focusing solely on what is inside. While such methods may protect users from the mess largely by erasing it and other uncertainties from sight and consideration, they do little to analyze it. Instead we need to directly engage complexities and actively work against simplification (Clarke and Keller 2014). Another "theory-methods package" concern is the concept of "epistemological diversity," important in postcolonial and indigenous STS (and lively in contemporary qualitative inquiry and discussions of democracy and science). Epistemic diversity explicitly recognizes many "ways of knowing" or "local epistemologies" (e.g., Lock 2001). Early feminist scholars (e.g., Anzaldua 1987; Collins 1990) and early postcolonial STS (e.g., Watson-Verran and Turnbull 1995) attended to this quite seriously, however marginalized. The increasing import of epistemological diversity is due in no small part to both increased recognition of diverse "ways of knowing" and locations of knowledge production and to the fact that indigenous and (post)colonial scholars are today inside academia (e.g., E. Anderson 2006; Mertens, Cram and Chilisa 2014). Such works engage classic STS questions of relations between epistemic diversity and minority traditions in Fleck's ([1935] 1979) sense of "thought collectives." Among the exciting "openings" through postcolonial STS have been engagements of scholars from Asia, East Asia and beyond which have coalesced in the journal East Asian Science, Technology and Society since 2007, among other venues. Founding editors Daiwie Fu and Chia-ling Wu drew together an incredible array of scholars especially from South Korea, Taiwan and Japan to engage fundamental questions in postcolonial STS. Fu (2007) asked the provocative question: "How Far Can East Asian STS Go?" vis-à-vis theoretically and substantively extending STS. Lin and Law (2015) responded "We Have Never Been Latecomers!" and a number of scholars have joined this complex and important conversation (e.g., Chen 2012). Now published by Duke, EASTS is a "cross-over" journal, addressing both general and postcolonial STS issues. The successes of EASTS, South American and other venues of institutionalizing STS demonstrate the increasingly transnational acceptance of STS tools for asking important questions about technoscience, society and the pasts and futures of the planet.

IF Is there anything that worries you when you think about the future of STS?

AC I see several key challenges for the field today. First is "the great divide" between feminist STS and STS which often amounts to segregation, an unfortunate term but useful in describing a form of separation that, while marginalizing, is often complicated. Today, the dramatic growth of feminist STS in women's and gender studies transnationally sustains such developments in academia (including the new journal Catalyst). But such segregation is often re-inscribed unproductively. A second challenge is the persistent relative absence of scholars of color in both feminist STS and STS (Benjamin 2016). At the Feminist Caucus of $4 S$ in 1999, we acknowledged that while 
feminists could have all the sessions we wanted, the absence of scholars of color and scholarship on issues of race and racism in STS remained problematic. Michelle Murphy, Wenda Bauschspies and I then organized sessions for the 2001 meetings in Cambridge, MA, ending up with a stream of 14 sessions on "Race and Other Inequalities in/and Science, Technology, and Medicine" that spanned the entire conference. It was amazing. Similar efforts have been mounted by having $4 \mathrm{~S}$ meetings in Tokyo, Buenos Aires and Barcelona. But I worry that scholars of color are not recruited into more sustained participation. A third and rather skeptical worry concerns the discursive positioning of STS and feminist STS. Across the 20th century, different specialties have been mobilized to "mediate" between sciences, technologies, medicine and "society." (I rarely use that word but it works here.) Post WWII, medical sociology grew rapidly in the US with extensive federal funding as the US NIH (National Institutes of Health) and NIMH (National Institutes of Mental Health) initially flourished. Technology studies also grew at this time, commensurate with expansion of the NSF (National Science Foundation) during the Cold War. Then along came medical anthropology in the 1970s, soon followed by or in tandem with (largely philosophical) bioethics. And since the 1980s, STS and feminist STS have thrived, however separately. Given these developments, I remain concerned that any representation of a science or technology or medical development can be inherently hagiographic (see e.g., Abir-Am 1983). In the very doing of STS, are we serving as boosters, translators, legitimators and normalizers of science to the people rather than focusing on what sciences and technologies for the people (with our often quite heterogeneous needs) might be? I grow increasingly disturbed by conference papers which spend so long explaining the science that there is insufficient time and space for strong STS analysis! As Paul Wolpe (2010:110) noted, "Bioethics as a discipline therefore is torn between its potential role as a watchdog and critic and its function in lubricating the social acceptance of biotechnologies." I think such concerns are what David Hess (2009) is getting at in his work on "undone science." We focus so much on trying to grasp what is done or what is about to be done that we lose sight and track of what could have been done and, indeed, should have been done instead. A final and related challenge is that the effects of neoliberalism on higher education have been devastating for many social science projects and careers, especially for STS scholars and others who have no obvious "products" to sell—no "lubricants" as it were. That is, while the demands that academics secure funding from outside sources expand, the spaces, places and funding possibilities for critical STS grow smaller and smaller (e.g., Lave, Morowski and Randalls 2012). But all is not lost, as conferences such as "Neoliberalism and Biopolitics" at UC Berkeley in 2015 demonstrated. For me, these concerns grow in importance and have implications for enhancing democratic practices, as Irwin and colleagues (2013) argued. The next generations of STS scholars are already finding new and more widely effective venues for critical STS work in social media and beyond, such as Monica Casper's powerful work on The Feminist Wire. I'm very proud of contributing with Monica to four separate editions of Our Bodies Ourselves on the Pap smear. In my imagined future of STS, we could begin to 
take feminism writ large analytically for granted. That is, if there were gender or race or sexuality or disability or indigeneity or other issues of difference and inequality lively in the topic under study, we could rest assured that they would be at least adequately addressed by the researchers. Again, such issues need not be the sole analytic focus of a project, but should always be seriously engaged when present, and their consequences assessed. Ditto the "undone science."

IF Finally, what has excited you most about STS and where it seems to be going?

AC One of the greatest benefits of being in STS has been participating in a seriously transnational scholarly endeavor and developing collegial relationships in many parts of the world. My networks have taken me throughout Europe and Scandinavia, and into wonderful feminist STS worlds in the Netherlands (including a doctoral program called Women's Studies Biology in the 1980s, sadly gone now, via Nelly Oudshoorn and Marianne van den Wijngaard) deeply linked to India and elsewhere through activist histories. Trips to Taiwan and Tokyo deepened my grasp of what it might mean to have a truly more transnational STS. I was saddened at not being able to attend the 4 S meetings in Buenos Aires due to disability, as well as having to turn down invitations from afar. Such connections have been precious rewards across my career. While I taught (post)coloniality and STS for over a decade, my knowledge remains shallow. The emergence of Asia and South America in transnational STS in terms of new researchers, research topics and educational promotion has been profoundly educating to me and highly significant for the future of STS. Africa will likely be the next site of intensified focus, expanding important earlier work (e.g., by Helen Watson-Verran and Wes Schrum). My final futurist concern here centers on the politics of engagement. When I "came up" in STS, one had to be a disciple of this or that person or approach. Today I would argue that if knowledge is power, then promoting "one best way" concentrates it unproductively. In sharp contrast, valuing theoretical (or "theory-methods package") pluralism disperses that power (Yanow and Schwartz Shea 2006:390). Chantal Mouffe's (2000:102-103, emphasis in the original) concept of agonistic pluralism captures this well: Antagonism is struggle between enemies, while agonism is struggle between adversaries....[E]nvisaged from the perspective of "agonistic pluralism" the aim of democratic politics is to transform antagonism into agonism. This requires providing channels through which collective passions will be given ways to express themselves over issues which, while allowing enough possibility for identification, will not construct the opponent as an enemy but as an adversary....[F]or "agonistic pluralism", the prime task of democratic politics is not to eliminate passions from the sphere of the public...but to mobilize those passions towards democratic designs. Promoting engagement without domination or phony consensus amplifies both Straussian "cooperation without consensus" (e.g., Clarke and Star 2008) and "epistemic diversity" (e.g., E. Anderson 2006). Both engagement and cooperation are requisite for the kinds of bridging, "cross-over" and hybrid projects, journals and organizations that I wish to promote in concluding. My imagined ST\&MS futures are venues where people of different disciplinary, professional 
and other related cultures and commitments can together pursue innovative endeavors toward enhanced multispecies justice. For example, I had the honor of co-editing BioSocieties with Nik Rose and Ilina Singh, a journal which for over a decade has sought to bring life and social scientists to the same scholarly table with some success. A new more focused journal with a similar agenda, Reproductive BioMedicine and Society Online, was recently launched by Sarah Franklin and Martin Johnson. Cross-campus initiatives can also promote STS bridges. At UCSF, anthropologist Barbara Koenig, with whom I cotaught STS, founded the Center for Transdisciplinary ELSI Research in Translational Genomics, crossing organizational boundaries on our campus never before breached (see http://www.ct2g.org/). It includes a working group on "Race, Ethnicity, Gender and Genomics." At UC Santa Cruz, Jenny Reardon founded and co-directs the Science and Justice Research Center that innovates experimental civic spaces and collaborative research practices (see http://scijust.ucsc.edu/). Participants explore transdisciplinary topics such as biomedical innovation, species extinction, and big data through social justice lenses. ISHKABIBBLE is the nickname of the International Society for the History, Philosophy and Social Studies of Biology (ISHPSSB) which for nearly thirty years has succeeded at including both scientists and interested others (see http://ishpssb.org/. These are significant exemplars of transdisciplinary STS efforts that offer interested scientists venues to explore the social dimensions of science--and vice versa. Engagement without domination, cooperation without consensus and epistemic diversity are all important for the transnationalization of STS in ways that work against reinscribing imperial heritages. We will face many challenges of translation-linguistic, cultural, perspectival, epistemological, and even ontological-wherein cooperation will be of inestimable value for the future of STS.

\section{Imagining Alternative and Better Worlds: Political Engagement and STS}

\section{BY ISABEL FLETCHER}

I first read Our Bodies Ourselves—-the famous feminist health self-help manual—in the early 1980s, a few years before I encountered science and technology studies (STS), and two decades before I began my postgraduate studies in the field. I was thus both delighted and honored when I found that Adele Clarke, my interviewee for the Talking STS project, was one of the early contributors to 
Our Bodies Ourselves. It felt like a validation of my teenage self as well as of many of the political projects that are still important to both of us.

Adele Clarke's engagement with STS is deeply political. It developed out of her activism in the women's health movement in the 1970s, and commitments to feminism, anti-racism, and anti-colonialism remain at the heart of her vision of the discipline:

STS was one among an array of more or less politically-inspired transdisciplinary fields with its roots in what are now called 1960s politics...if there was a "long civil rights movement"...there was also a "long feminist STS movement" (p.6).

In the 1970s, feminists were the main group—both inside and outside of academia-developing social scientific understandings and critiques of reproductive medicine. Their work since then has formed an important part of contemporary STS approaches to the life sciences (Firestone 1970; Arditti et al. 1984; Correa 1985; Rowland 1992; and Ginsberg \& Rapp 1995). However, as Clarke acknowledges, the relationship between feminist thought and practice and STS, whilst productive, has also been problematic. She describes, "struggle and strife both within and among the disciplines that have taken science, technology, and medicine studies seriously" (p.13). For example, researchers using feminist approaches at times have struggled for credibility and authority within STS, as they have in the social sciences more generally. Clarke argues that this has led to a "great divide" between STS and feminist STS, which often leads to segregation of both outputs and individuals.

Clarke also worries about a lack of diversity within both contemporary feminist STS and STS more generally. She describes how nearly two decades ago, the Feminist Caucus of the Society for Social Studies of Science (4S) saw the absence of scholars of color, and scholarship on race and racism, as a problem. In 2001 she was one of the organizers (with Michelle Murphy and Wenda Bauchspies) of a very successful conference stream on "Race and Other Inequalities in/and Science, Technology and Medicine." However, in her opinion, both STS and feminist STS remain relatively un-diverse. Nonetheless, she is hopeful about the increasing amount of STS research being done in South America, South Korea, Taiwan and Japan, including East Asian Science, Technology and Society. She argues that "Africa will probably be the next site of greater focus" (p.24).

Clarke's politics inform both the topics that she thinks are important for STS and her theoretical and methodological approaches to research. Her explicit political commitments are unusual amongst our interviewees and in contemporary STS, in which activist approaches are becoming increasingly unfashionable and hard to sustain under the pressure of the contemporary academic job market. Clarke herself describes the 1990s Science Wars and contemporary neoliberal approaches to university governance as having negative effects on the development of STS. I would argue that scholars whose work is politically engaged are more vulnerable to resulting pressures such as precarious employment, which act to create political and academic conformity. 
For Clarke, STS is, by history and necessity, an inter- or trans-disciplinary activity. Her "origin story" for STS highlights the contributions of three groups: those in Scandinavia working on science, computing, and society; STS units in Edinburgh, Bath, Paris, and Bielefeld; and STS/science policy scholars in the United States at Rensselaer Polytechnic Institute, Virginia Tech, and Georgia Institute of Technology, and elsewhere. For many of our interviewees this inter- or trans-disciplinary nature of early STS made it innovative and exciting. For Clarke, unlike other interviewees, these collaborations seem to have remained largely productive, despite their tensions.

Clarke's commitment to inter-/trans-disciplinary approaches is reflected in her description of important collaborations across many disciplines-from studies in the history of biology in her early career to her current project on Making Kin, Not Population. Giving a useful and specific example, she argues that although contributing to edited volumes and journal special issues is "undervalued," such activities are important means of developing and strengthening collaborative networks. Throughout the interview, Clarke is generous in acknowledging the work of her collaborators and others who have influenced her work. Without being complacent, she gives a vivid sense of how $4 \mathrm{~S}$ has become a "comfortable transnational forum" for trans-disciplinary scholars working, for example, in the area of reproduction.

Other interviewees, including Barry Barnes and Karin Knorr Cetina, also discuss the importance of working across disciplinary boundaries. Like them, Clarke sees such approaches as integral to the future of STS, as they will contribute new topics and new approaches, and increase the diversity of practitioners within the field. Implied throughout her account is wariness of allegiance to any one theoretical or methodological account of the world, and recognition of the value of "epistemological diversity" and different "ways of knowing" (p.20). Much of this derives from feminist theory and practice, and I find it refreshing to see it presented as central to the academic program of STS.

Both Clarke and Sheila Jasanoff highlight the poor quality of some STS training as a problematic aspect of inter-/trans-disciplinarity. Clarke is frustrated by the ways in which authors--both of journal articles and books-make poor use of existing approaches and appear unaware of previous work on particular topics. Her solution is better training for doctoral students and newcomers to STS in established "theory-method packages" e.g., actor-network theory, grounded theory/situational analysis etc., and more attention to methods and adequate citation in peer review processes. She is clear that the issues that led her into STS remain pertinent and that there is great value in revisiting "old" questions and debates, since such "refreshing" contributes to the future of STS. What worries her is producing poor scholarship by not learning from, and acknowledging, earlier approaches. I suggest this concern is related to the character of STS itself. It is a relatively young, inter-/trans-disciplinary field, with indistinct and porous boundaries, that has grown significantly and become influential in other disciplines, including education, informatics, and sociology. However, this expansion has led to confusion about what it is to "do STS." We need to find a balance between expansion, inclusiveness, and innovation, and retaining a coherent academic identity. Clarke's call for attention to the historical 
"roots" and accomplishments of STS resonates with other interviewees' arguments that, in order to progress, the field needs to go back to its origins.

Another problematic development Clarke discussed was the institutionalization of inter/ trans-disciplinarity via the embedding of STS in large STEM projects in which it may be expected to act as a "service" discipline-mediating relations between science and its publics. This development raises important questions about the obligations of STS researchers and our attitudes toward the materials and practices that we study. Clarke worries that representation of these developments may be "inherently hagiographic." I share this concern about my work on obesity, and vis-a-vis social scientific approaches to biomedical innovation in general. However, it seems equally problematic for STS researchers to give up on the possibility of analyzing powerful social institutions. A better approach, as Clarke asserts, may be to focus on "undone science" (Hess, 2009): "We focus so much on trying to grasp what is done or what is about to be done that we lose sight and track of what could have been done and indeed should have been done instead."

This focus on the undone science is, for me, one of STS's and indeed the social sciences' most powerful political tools: the imagining of alternative and better worlds. Such imagination is a vital source of the political commitment that underlies Clarke's work. It is important because it can combat the neo-liberal de-politicization of social scientific research by developing robust and socially useful critiques of unjust technologies and practices. Such approaches are becoming rare in our field and in academia more generally, so it was very inspiring to interview someone who sees it as integral to our work and as a key to the future success of our field.

\section{Author Biography}

Adele Clarke obtained a B.A. in sociology in 1966 from Barnard College and an MA in sociology in 1970 from NYU. She then moved on to teach various places including women's studies at Sonoma State University before moving to the University of California, San Francisco (UCSF) to write her PhD, completed in 1985. After a postdoctoral fellowship at Stanford University, she returned to UCSF as an Assistant Professor in 1989. She was tenured in 1992 and promoted to Professor in 1998. Clarke is the author of several books and articles including the award winning Disciplining Reproduction: American Life Scientists and the "Problem of Sex" (University of California Press, 1998) She also co-edited a volume focused on scientific practice entitled The Right Tools for the Job: At Work in Twentieth Century Life Sciences (Princeton University Press, 1992; French trans., Synthelabo Groupe, 1996). Her most recent STS work is the co-edited volume entitled Biomedicalization: Technoscience, Health and Illness in the US (Duke University Press, 2010). Clarke also developed a method of qualitative inquiry used in STS and many other fields. Her books here include Situational Analysis: Grounded Theory After the Postmodern Turn (Sage 2005; German trans., Verlag für Sozialwissenschaften, 2012; 2 ${ }^{\text {wa }}$ ed. co-authored with Carrie Friese and Rachel Washburn, Sage, 2018), and Situational Analysis in Practice: Mapping Research with Grounded Theory (co-edited with Carrie Friese and Rachel Washburn, Routledge, 2015). Her publications have contributed to knowledge and advanced theory in medical sociology, science and technology 
studies, anthropology, feminist studies, and beyond. Professor Clarke was awarded the $2012 \mathrm{~J}$. D. Bernal Prize for Outstanding Contributions by the Society for Social Studies of Science, and the 2015 Leo G. Reeder Award for Distinguished Contribution to Medical Sociology by that section of the American Sociological Association.

\section{Author Biography}

Isabel Fletcher is a qualitative social scientist whose research focuses the interactions between nutrition research and public health policy. Her Ph.D. research at the University of Edinburgh was a historical account of the construction of the obesity epidemic, and spanned medical sociology, public health policy and the history of medicine. She has subsequently worked on food security policy and commercial actors' understandings of public health regulation. Currently, she works with Professor Graeme Laurie on the Wellcome Trust funded project "Confronting the Liminal Spaces of Health Research Regulation." She is using the case study of sustainable eating to examine interactions between nutrition and environment policy.

\section{References}

Abir-Am, Pnina. 1985. "Themes, Genres and Orders of Legitimation in the Consolidation of New Disciplines: Deconstructing the Historiography of Molecular Biology." History of Science 23:73-117.

Amsterdamska, Olga and Anja Hiddinga. 2004. "Trading Zones or Citadels? Professionalization and Intellectual Change in the History of Medicine." In Locating Medical History: The Stories and their Meanings, edited by F. Huisman and J. Harley Warner, 237-261. Baltimore: Johns Hopkins University Press.

Anderson, Elizabeth. 2006. "The Epistemology of Democracy." Episteme 3(1-2):8-22.

Anderson, Warwick. 2015. "Postcolonial Science Studies." International Encyclopedia of the Social and Behavioral Sciences, edited by J. D. Wright, 2 ${ }^{\text {nd }}$ ed. 18:652-657.

Anderson, Warwick, and Vincanne Adams. 2007. "Pramoedya's Chickens: Postcolonial Studies of Technoscience." The Handbook of Science and Technology Studies 181-204. Cambridge, MA: MIT Press.

Anzaldua, Gloria. 1987. Borderlands/La Frontera: The New Mestiza. San Francisco: Aunt Lute Press.

Arditti, Rita, Pat Brennan and Steve Cavrak. (Eds.) 1980. Science and Liberation. Boston: South End Press.

Arditti, Rita, Renate Duelli Klein, and Shelley Minden (Eds) 1984. Test-tube Women: What Future for Motherhood? London: Pandora Press.

Bailey, Moya and Whitney Peoples. 2017. "Towards a Black Feminist Health Science Studies." Catalyst: Feminism, Theory, Technoscience 3(2) @ http:/ / catalystjournal.org/ojs/index.php/catalyst/article/view/120/html_17Barnes, Barry. 1977. Interests and the Growth of Knowledge. London: Routledge and Kegan Paul. 
Benjamin, Ruha. 2016. "Catching Our Breath: Critical Race STS and the Carceral Imagination." Engaging Science, Technology, and Society 2:145-156.

Benson, Keith, Jane Maienschein, and Ronald Rainger. (Eds.) 1991. The Expansion of American Biology. New Brunswick, NJ: Rutgers University Press.

Berger, Peter and Thomas Luckman. 1966. The Social Construction of Reality: A Treatise in the Sociology of Knowledge. New York: Doubleday.

Bowker, Geof, Stefan Timmermans, Adele E. Clarke and Ellen Balka. (Eds.) 2015. Boundary Objects and Beyond: Working with Susan Leigh Star. Cambridge, MA: MIT Press.

Casper, Monica J. 2016. “But Is It Sociology?" Engaging Science, Technology, and Society 2:208-213.

Casper, Monica J. and Marc Berg. 1995. "Introduction: Constructivist Perspectives on Medical Work: Medical Practices and Science and Technology Studies." Science, Technology, and Human Values 20(4):395-407.

Chen, Jia-shin. 2012. "Rethinking East Asian Distinction: An Example of Taiwan's Harm Reduction Policy." East Asian Science, Technology and Society: An International Journal. 6(4):453-464.

Chubin, Daryl and Ellen W. Chu. 1989. Science off the Pedestal: Social Perspectives on Science and Technology. Belmont, CA: Wadsworth Pubs.

Clarke, Adele E. 1984. "Subtle Sterilization Abuse: A Reproductive Rights Perspective." In Test Tube Women: What Future for Motherhood? edited by Rita Arditti, Renate Duelli Klein and Shelly Minden, 188-212. Boston: Pandora/Routledge and Kegan Paul.

Clarke, Adele E. 1998. Disciplining Reproduction: Modernity, American Life Sciences and the "Problem of Sex." Berkeley: University of California Press.

Clarke, Adele E. 2007. "Reflections on the Reproductive Sciences in Agriculture in the UK and US, c1900-2000." In Special Issue on Agricultural Sciences, edited by Sarah Wilmot. History and Philosophy of the Biological and Biomedical Sciences 38(2):316-339.

Clarke, Adele E. 2008. "Introduction: Gender and Reproductive Technologies in East Asia." EASTS: East Asian Science and Technology Studies: An International Journal 3(1):303-326.

Clarke, Adele E. 2016. "Situating STS and Thinking Ahead." Engaging Science, Technology, and Society 2:157-179.

Clarke, Adele E. and Kathy Charmaz. (Eds.) 2014. Grounded Theory and Situational Analysis. Sage Benchmarks in Social Research, 4 volumes. London: Sage.

Clarke, Adele E., Carrie Friese and Rachel Washburn. (Eds.) 2015. Situational Analysis in Practice: Mapping Research with Grounded Theory. Walnut Creek, CA: Left Coast Press.

Clarke, Adele E., Carrie Friese and Rachel Washburn. 2018. Situational Analysis: Grounded Theory After the Interpretive Turn. Thousand Oaks, CA: Sage, $2^{\text {sd }}$ ed.

Clarke, Adele E. and Donna Haraway (Eds.) Forthcoming 2018. Making Kin Not Population. London: Prickly Paradigm Press.

Clarke, Adele E. and Susan Leigh Star. 2008. "Social Worlds/Arenas as a Theory-Methods Package." In Handbook of Science and Technology Studies, edited by E. Hackett, O. Amsterdamska, M. Lynch and J. Wacjman, 113-137. Cambridge, MA: MIT Press, 3rd ed. 
Clarke, Adele E. and Alice Wolfson. 1984. "Class, Race and Reproductive Rights." Socialist Review 78:110-120. Reprinted in Women, Class and the Feminist Imagination: A Socialist-Feminist Reader, edited by Karen V. Hansen and Ilene J. Philipson, 258-267. Philadelphia: Temple University Press.

Clarke, Adele in Conversation with Reiner Keller. 2014. "Engaging Complexities: Working Against Simplification as an Agenda for Qualitative Research Today." FQS Forum: Qualitative Social Research 15(2) http://www.qualitativeresearch.net/index.php/fqs/article/view / 2186

Collins, Harry. 1983. "An Empirical Relativist Program in the Sociology of Scientific Knowledge." In Science Observed: Perspectives on the Social Study of Science, edited by Karen Knorr-Cetina and Michael Mulkay, 85-114. London: Sage.

Collins, Patricia Hill. 1990. Black Feminist Thought: Knowledge, Consciousness, and the Politics of Empowerment. Boston: Unwin Hyman.

Epstein, Steven. 2016. "Positioning the Field: STS Futures." Engaging Science, Technology, and Society 2:140-144.

Fleck, Ludwik. [1935] 1979. The Genesis and Development of a Scientific Fact. Chicago: University of Chicago Press.

Fu, Daiwe. 2007. “How Far Can East Asian STS Go?” EASTS: East Asian Science, Technology and Society: An International Journal 1:1-14.

Gad, Christopher and David Ribes. 2014. "The Conceptual and Empirical in Science and Technology Studies." Science, Technology and Human Values 39(2):183-191.

Greeley, Kathy and Sue Tafler. 1980. "History of Science for the People: A Ten Year Perspective." In Science and Liberation, edited by Rita Arditti, Pat Brennan and Steve Cavrak, 369-388. Boston: South End Press.

Haraway, Donna. 1985. “A Manifesto for Cyborgs: Science, Technology, and Socialist Feminism in the Last Quarter." Socialist Review 80:65-107. Reprinted in Women, Class and the Feminist Imagination: A Socialist-Feminist Reader, edited by Karen V. Hansen and Ilene J. Philipson, 580-618. Philadelphia: Temple University Press, 1990.

Haraway, Donna. 1989. Primate Visions: Gender, Race, and Nature in Modern Science. NY: Routledge.

Haraway, Donna. 2007. When Species Meet. Minneapolis: University of Minnesota Press.

Hess, David J. 2009. "The Potentials and Limitations of Civil Society Research: Getting Undone Science Done." Sociological Inquiry 79:306-327.

Hilgartner, Stephen. 1997. "The Sokal Affair in Context." Science Technology Human Values 22(4):506-522.

Irwin, Alan, Torben Elgaard Jensen, and Kevin E. Jones. 2013. "The Good, the Bad and the Perfect: Criticizing Engagement Practice." Social Studies of Science 43:118-135.

Kohn, Eduardo. 2013. How Forests Think: Toward an Anthropology Beyond the Human. Berkeley: University of California Press.

Kuhn, Thomas. [1962] 1996. The Structure of Scientific Revolutions. Chicago: University of Chicago Press, $3^{\text {ra }}$ ed. 
Latour, Bruno. 1983. "Give Me a Laboratory and I will Raise the World." In Science Observed: Perspectives on the Social Study of Science, edited by Karen Knorr-Cetina and Michael Mulkay, 141-170. London: Sage.

Latour, Bruno. 1986. "Visualization and Cognition: Thinking with Eyes and Hands." In Knowledge and Society: Studies in the Sociology of Culture Past and Present Special Issue edited by Henrika Kuklick and Elizabeth Long, 6:1-40.

Latour, Bruno. 2013. Facing Gaia: A New Inquiry into Natural Religion. The University of Edinburgh Gifford Lectures. See http:/ / www.bruno-latour.fr/node/487

Law, John. 2004. After Method: Mess in Social Science Research. London: Routledge.

Law, John. 2007. "Making a Mess with Method.", 595-606. In Handbook of Social Science Methodology edited by William Outhwaite and Stephen P. Turner. Thousand Oaks, CA: Sage.

Law, John and Vicky Singleton. 2005. “Object lessons.” Organization 12(3):331-355.

Lin, Wen-Hua and John Law. 2015. "We Have Never Been Late-comers! Making Knowledge Spaces for East Asian Technosocial Practices." EASTS: East Asian Science, Technology and Society: An International Journal 9(2):117-126.

Lock, Margaret. 2001. "The tempering of medical anthropology: Troubling natural categories." Medical Anthropology Quarterly 15(4):478-492.

Lury, Celia and Nina Wakeford. (Eds.) Inventive Methods: The Happening of the Social. London: Routledge, 2012.

MacKenzie, Donald. 1978. "Statistical Theory and Social Interests: A Case Study." Social Studies of Science 8:35-83.

MacKenzie, Donald. 1982. "Technology as Capitalist Restructuring." [Review of Levidow and Young, Science, Technology, and the Labour Process.] Radical Science Journal 12:141-145.

Mertens, D.M., F. Cram, and B. Chilisa (Eds.) 2014. Indigenous Pathways into Social Research: Voices of a New Generation. Walnut Creek, CA: Left Coast Press.

Nelson, Alondra. 2013. Body and Soul: The Black Panther Party and the Fight against Medical Discrimination. Minneapolis: University of Minnesota Press.

Prasad, Amit. 2016. "Discursive Contextures of Science: Euro/West-Centrism and Science and Technology Studies." Engaging Science, Technology, and Society 2:193-207.

Raffles, Hugh. 2011. Insectopedia. New York: Vintage.

Rapp, Rayna. 2001. "Gender, Body, Biomedicine: How Some Feminist Concerns Dragged Reproduction to the Center of Social Theory." Medical Anthropology Quarterly 15(4):466-477.

Ravetz, Jerome R. 1971. Scientific Knowledge and its Social Problems. Oxford: Clarenden Press.

Rodriguez-Muniz, Michael. 2016. "Bridgework: STS, Sociology, and the 'Dark Matters' of Race." Engaging Science, Technology, and Society 2:214-226.

Saetnan, Anne, Nelly Oudshoorn and Marta Kirejczyk (Eds.) 2000. Bodies of Technology: Women's Involvement with Reproductive Medicine. Columbus: Ohio State University Press.

Shapin, Steven. 1995. "Here and Everywhere: Sociology of Scientific Knowledge." Annual Review of Sociology 21:289-321. 
Star, Susan Leigh. 1979. "Sex Differences and Brain Asymmetry: Problems, Methods and Politics in the Study of Consciousness." In Genes and Gender II: Pitfalls in Research on Sex and Gender, edited by Ruth Hubbard and Marian Lowe, 113-130. New York: Gordian Press.

Star, Susan Leigh. [1988] 1989a. "The Structure of Ill-Structured Solutions: Boundary Objects and Heterogeneous Distributed Problem Solving." Reprinted in Distributed Artificial Intelligence 2, ed. M. Huhns and L. Gasser, 37-54. Menlo Park: Morgan Kauffmann, 1989. Reprinted in Boundary Objects and Beyond: Working with Susan Leigh Star, edited by Geof Bowker, Stefan Timmermans, Adele E. Clarke and Ellen Balka. 243-259. Cambridge, MA: MIT Press, 2015.

Star, Susan Leigh. 1989b. Regions of the Mind: Brain Research and the Quest for Scientific Certainty. Stanford, CA: Stanford University Press.

Star, Susan Leigh. 1991. "Power, Technologies and the Phenomenology of Conventions: On Being Allergic to Onions." In A Sociology of Monsters: Essays on Power, Technology and Domination edited by J. Law, 25-56. New York: Routledge.

Star, Susan Leigh (Ed.) 1995a. "Introduction." Ecologies of Knowledge: Work and Politics in Science and Technology. Albany: State University of New York Press. Reprinted in Boundary Objects and Beyond: Working with Susan Leigh Star, edited by Geof Bowker, Stefan Timmermans, Adele E. Clarke and Ellen Balka, 13-46. Cambridge, MA: MIT Press, 2015.

Star, Susan Leigh. 1995b. "The Politics of Formal Representations: Wizards, Gurus, and Organizational Complexity." In Ecologies of Knowledge: Work and Politics in Science and Technology, edited by Susan Leigh Star, 88-118. Albany, N.Y.: State University of New York Press.

Star, Susan Leigh. 2010. "This is Not a Boundary Object: Reflections on the Origin of a Concept." Science, Technology and Human Values 35:601-617.

Star, Susan Leigh and James Griesemer. 1989. “Institutional Ecology, Translations, and Boundary Objects: Amateurs and Professionals in Berkeley's Museum of Vertebrate Zoology, 1907-39." Social Studies of Science 19:387-420. Reprinted in The Science Studies Reader, edited by M. Biagioli, 505-524. New York: Routledge, 1999. Reprinted in Boundary Objects and Beyond: Working with Susan Leigh Star, edited by Geof Bowker, Stefan Timmermans, Adele E. Clarke and Ellen Balka, 171-200. Cambridge, MA: MIT Press, 2015.

Sweeney, Elizabeth M. 2015. "Shifting Paradigms on the Verge of a Revolution: The Evolution of the ASA Section on Science, Knowledge, and Technology." In SKATOLOGY: Newsletter of the Science, Knowledge, and Technology Section of the ASA. Spring edition. 4-9.

Watson-Verran, Helen and David Turnbull. 1995. "Science and Other Indigenous Knowledge Systems." In Handbook of Science and Technology Studies edited by Sheila Jasanoff, Gerald E. Markle, J. Petersen and Trevor Pinch, 115-139. Thousand Oaks, CA: Sage.

Wersky, Gary. 1978. The Visible College: The Collective Biography of British Scientific Socialists of the 1930s. New York: Holt, Reinhart and Winston.

Wolpe, Paul R. 2010. "Professionalism and Politics: Biomedicalization and the Rise of Bioethics." In Progress in Bioethics: Science, Policy, and Politics. edited by J. D. Moreno and Sam Berger, 109-118. Cambridge, MA: MIT Press. 
Woolgar, S. and J. Lezaun. 2013. "The Wrong Bin Bag: A Turn to Ontology in Science and Technology Studies?" Social Studies of Science 43(3):321-340.

Wu, Chia-Ling, Yu-ling Huang, Young-Gyung Park, and Adele E. Clarke. 2008. "Gender and Reproductive Technologies in East Asia: A Partial Bibliography of Works in English." East Asian Science and Technology Studies: An International Journal 3(1):327-334.

Yanow, D. and Schwartz-Shea, P. 2006. "Doing Social Science in a Humanistic Manner."In Interpretation and Method: Empirical Research Methods and the Interpretive Turn edited by Dvora Yanow and Peregrine Schwatrz-Shea, 380-394. Armonk, New York and London, England: M.E. Sharpe.

Zilsel, Edgar. [1942] 2000. “The Sociological Roots of Science.” Social Studies of Science 30(6):935949.

Zuckerman, Harriet. 1989. "The Sociology of Science." In Handbook of Sociology edited by Neil Smelser, 511-574. Newbury Park, CA: Sage. 